\title{
Kozioł dla Azazela
}

Tekst z Kpł 16 opisujący ryt Dnia Pojednania zawiera w sobie wielce tajemniczą i intrygującą informację o koźle odsyłanym na pustynię. Równie ciekawy jest sam termin ' $\breve{a} z \bar{a}$ 'zél wraz z problematycznym w interpretacji hebrajskim przedrostkiem $l^{e}$. Jakie jest kulturowe i biblijne tło tego określenia? Odpowiedź na to pytanie będzie treścią niniejszego artykułu.

Tekst kapłański Kpł 16, główne źródło informacji o kultycznej roli kozła przeznaczonego dla tajemniczego Azazela w ramach opisu rytu Dnia Pojednania, nie definiuje gatunkowo tego zwierzęcia. Używa na określenie kozła terminu śấ $\hat{\imath} r$. Nie jest to jednak ani jedyne, ani najstarsze określenie kozła. W Rdz 15, 9 znajdujemy pochodzące zapewne ze środowiska pasterskiego określenie ' $\bar{e} z$. Ponieważ tekst hebrajski nie zawiera tu zróżnicowania płci, wnosić można o takim zróżnicowaniu z przekładu

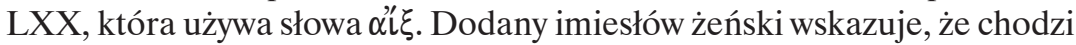
tutaj o „kozę”. Jednak w dwóch innych przypadkach LXX daje zupełnie odmienne tłumaczenie. Chodzi tu o Rdz 27, 9 i 16, gdzie ten sam hebrajski termin ‘ēz LXX przekłada przez ‘’ Rdz 15, choćby z racji ubóstwa języka, może zawierać dość wczesną warstwę językową, wywodzącą się z tradycji seminomadycznej. Jednakże w Rdz

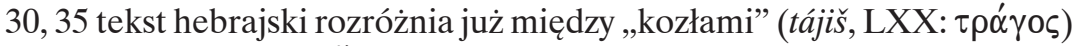
i „kozami” ('éz, LXX: $\alpha$ 'c $\xi$ - por. Rdz 31, 38). Ciekawe jest to, że ‘éz oznacza „kozy”, a na oznaczenie „kozłów” użyty został termin tájiš. Ostatni termin występuje w ST jeszcze tylko jeden raz w Prz 30, 31. Jeszcze ciekawsze jest

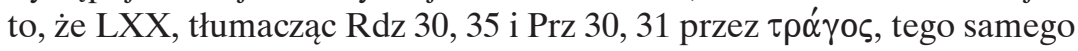
określenia używa dla oddania hebrajskiego terminu śa $\hat{a} i ̂ r$, przy czym ma to miejsce wyłącznie w tekstach późnych: Kpł 16, 22; Lb 7, 16. 28. 34. 40. 46. 52. 58. 64. 70. 76. 82; 28, 15; Dn 8, 5. 8. 21.

Uznawany za późną warstwę kapłańską tekst Lb 7 i inne teksty kapłańskie z Księgi Kapłańskiej dokonują zabiegu szczególnego. Łączą bowiem używany niezależnie we wczesnych tekstach termin śâ $\hat{i} r$ na oznaczenie „kozła” jako ofiary przebłagalnej (hatț $\bar{a} \underline{t}$ ) z terminem ' $\bar{e} z$ oznaczającym 
rodzajowo „koźlęta”, przy czym są to zwierzęta należące do stada hodowlanego. Jakie znaczenie ma owo połączenie? Być może chodzi o jasne wyłuszczenie, że w świątynnej ofierze przebłagalnej winno być użyte zwierzę hodowlane, a nie zwierzę dzikie, przebywające $\mathrm{z}$ natury poza ludzkimi siedzibami. Kojarzyło się ono bowiem z symboliką demoniczną, a więc z negatywnymi wpływami na kształt religii izraelskiej.

Świadczy o tym używanie przez środowisko kapłańskie określenia śa î̀ $^{\prime}$ na oznaczenie demonów: „Odtąd nie będą składać ofiar demonom (laśśs î̀rim), z którymi uprawiali nierząd" (Kpł 17, 7). Takie rozumienie potwierdza środowisko kronikarskie. Teksty kronikarskie za jedno z najbardziej dramatycznych wydarzeń w historii Izraela uznają secesję Jeroboama. Jej skutkiem stała się idolatria: „Sam sobie ustanawiał kapłanów na wyżynach dla czczenia kozłów (welaśśe ‘îrîm) i cielców, które sporządził” (2 Krn 11, 15). Rozumienie cielca w kontekście całej Biblii jest względnie oczywiste. Natomiast kozioł-demon w rozumieniu tych tekstów jednoznacznie jest związany z pojęciem nieczystości sakralnej. Cielec byłby więc tu znakiem zaprzeczenia przymierzu, przywołuje bowiem myśl o znanej scenie spod Synaju. Kozioł zapewne oznacza tutaj w przeczaccym, negatywnym znaczeniu, ideę wyboru Izraela na lud Boży. Analogia do nocy paschalnej w Egipcie i oznaczenia odrzwi domów krwią baranka, gdyby ją przyjąć, wyjaśniałaby symbolikę kozła jako demoniczne zaprzeczenie więzi narodu z Bogiem poprzez fakt istnienia synkretycznych bądź wręcz kultów obcych bóstw ${ }^{1}$.

Utwierdza w tej opinii interpretacja opisu dnia Jahwe u Iz 13 jako jednego ze skutków gniewu Jahwe wobec Babilonu. Jest nim spustoszenie miasta i zamieszkanie tam zwierząt pustynnych: „Dziki zwierz tam mieć będzie swe leże, sowy napełnią ich domy, strusie się tam zagnieżdżą i kozły ( $\hat{u}^{\text {se }}$ îrîm) będą harcować” $(\mathrm{Iz} 13,21)$. Owe kozły rozumiane są tu jako dzikie zwierzęta pustynne i według niektórych badaczy wyobrażają kananejskie bóstwo deszczu, wg innych zaś są istotami demonicznymi. Zresztą tak to zrozumiała LXX i przetłumaczyła jako $\delta \alpha \iota \mu o ́ \nu \iota \alpha$. Analogiczne rozumienie mamy w innym tekście Izajasza (Iz 34, 14). Opis efektów dnia Jahwe wobec Edomu jest wielce ciekawy: „Dzikie psy spotkają się z hienami i z kozłem ( $w^{e} s \hat{a} \hat{\imath} r$, LXX: $\left.\delta \alpha \iota \mu o ́ \nu \iota \alpha\right)$ będą się przyzywać wzajemnie; co więcej, tam lilit

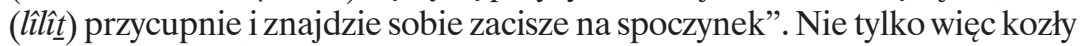
rozumiane są tutaj jako zwierzęta nieprzystępnej i demonicznej pustyni, ale tekst wprost mówi o ich personifikacji w postaci żeńskich demonów pustynnych - lilit. Psy i hieny LXX oddaje jednakowo, przez tajemnicze:

${ }^{1}$ Utożsamienie demona i boga znajdujemy w mitologicznej religii perskiej, gdzie demona dew wywodzi się z terminu o tym samym rdzeniu daewa, oznaczającego bóstwo lub boga fałszywego - zob. V. S. CurTis, Mity perskie, tłum. J. D. Artymowski, Warszawa 2000, s. 25. 


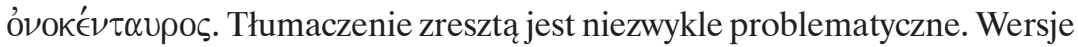
anglojęzyczne oddają to najczęściej przez: „wildcats”, „satyrs” i „lilith”. Można z dużym prawdopodobieństwem przyjąć, że w BH u Iz 13 i 34 termin śa ${ }^{\prime} \hat{i} r$ stosuje autor na wyobrażenie miast zniszczonych przez Boga, które stały się pustynią a zamieszkałe są przez istoty demoniczne pod postacią kosmatych kozłów.

Wśród wszystkich zwierząt tego kręgu dla Izraela najbardziej znany zapewne na zasadzie przeciwieństw był dziki, pustynny kozioł, a to stąd, że kozły i kozy były zwierzętami przez Izraelitów hodowanymi. Niemniej jednak kozioł pustynny był przedstawicielem tajemniczej i negatywnej rzeczywistości religijnej, kulturowo przeciwnej dobru i destrukcyjnej. Powiedzieć trzeba, że kozły „odgrywały pewną przynajmniej rolę w synkretycznym kulcie ostatnich lat monarchii, a nawet później"2.

Kim jest tajemnicza lilit? W literaturze ugaryckiej jest boginią, którą czci się przez składanie ofiar, i zdaje się być utożsamiana z babilońską boginią płodności i cielesnej rozkoszy Inanną (Isztar). Najstarsze dane odnoszą to określenie do sumeryjskiej bogini Lilitu, która ma swoje odpowiedniki w kulturze Akkadu, Asyrii, Syrii. Dzieci Lilit nazywają się lilim. Ma to swoje odzwierciedlenie w hebrajskim terminie 'ělîlîm używanym zarówno przed deportacją jak i w podeportacyjnych tekstach biblijnych na oznaczenie bóstw obcych - idoli. Nie mają one żadnej mocy stwórczej i stąd w rzeczywistości nie istnieją (por. 1 Krn 16, 26; Ps 95, 6; Iz 2, 8; Ez 30, 13). Według Hab 2, 18 są to materialne posągi, które nie mają w sobie życia. Targum Jerozolimski, przekładając na język aramejski tekst Lb 6, 26 (tzw. błogosławieństwo Aarona), zinterpretował „dar pokoju” jako ochronę przed 'ělillîm. Oznacza to, że w okresie targumicznym tradycja o lilim była nie tylko znana, ale wyrażała ideę zagrożenia ze strony politeistycznych wpływów helleńskich, które sprzeciwiały się jedyności Jahwe, Boga Izraela, Boga przymierza.

Generalnie mówiąc, tekst Iz 13, 21 i Iz 34, 14 przedstawia świat tajemniczy, budzący grozę, demoniczny, który zapewne jako taki istniał w świadomości hebrajskiej. U kresu Drugiej Świątyni odzwierciedlał zakusy hellenizmu na monoteizm izraelski. Ten demoniczny świat, poczynając już od kręgu kulturowo-religijnego Sumerów, wywierał przemożny wpływ na poglądy religijne i religijną obrzędowość starożytnych.

Wielu komentatorów jest zdania, że w pismach biblijnych pobrzmiewa echo starożytnych mitów, w których Bóg walczy z demonicznym światem potworów. Pokutne ryty oczyszczeń biblijnych byłyby odbiciem antycznych, religijnych rytów magicznych, często powiązanych z medycyną, jakkol-

${ }^{2}$ L. Stachowiak, Księa Izajasza I. 1-39, Poznań 1996, s. 282.

${ }^{3}$ H. TAwIL, 'Azazel The Prince of the Steepe. A Comparative Study, ZAW 92 (1980) f. 1, s. 36. 
wiek same nie mają charakteru magicznego. Obrzędy takie praktykowano w starożytnej Mezopotamii, Egipcie, Azji Mniejszej i w wielu innych regionach starożytnego świata ${ }^{4}$. Jedną z idei tych obrzędów była wywodząca się z Mezopotamii idea substytucji uwidoczniona - jak się wydaje - w Kpł 16, a w literaturze określana też mianem „magicznej eliminacji”. Akkadyjski magiczny tekst klinowy mówi wprost o wyganianiu spośród ludzi demonów przynoszących choroby, zniszczenie i śmierć do ich naturalnego miejsca zamieszkania. Jest nim świat podziemny, źródło wszelkiego zła ${ }^{6}$. Ów świat demoniczny starożytne teksty opisują jako teren pełen nieprzystępnych urwisk, określanych mianem „Zachodu”. Inny tekst babiloński mówi o tym, że przyczynę zła należy odesłać do jego źródła; chorobę zaś należy transferować z ciała chorego na kozła, który następnie ma być „roztrzaskany” na urwiskach pustyni ${ }^{7}$. Babiloński traktat mądrościowy Ludlul bel nemeqi zwany też Babilońskim Jobem wyraża przekonanie o sile Marduka, który był mocen wygnać demony sprawiające ludzkie nieszczęścia do podziemnych głębokości, gdzie było ich pierwotne miejsce zamieszkania. W literaturze znaleźć można przekonanie, że istnieje związek między imieniem Azazel z Kpł 16 a huryckim ${ }^{8}$ terminem ofiarnym azazhum (azu zhi), który ma się wywodzić z rdzenia semickiego 9 . Przybliża nas to nieco do zrozumienia, jakie znaczenie może mieć w Kpł 16 odsyłanie kozła dla Azazela na pustynię.

Jakie znaczenie może mieć ten ryt w Kpł 16? Kpł 16, 5: „Od zgroma-

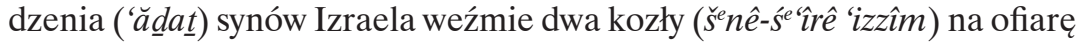
przebłagalną i jednego barana na ofiarę całopalną. Podstawową informacją jest tutaj fakt istnienia dwóch ofiar:

- ofiara przebłagalna (hațtâ’t ) z dwóch kozłów;

- ofiara całopalna ('ôla $(h))$ z barana.

Istotne jest to, że oba kozły i baran są ofiarowane przez sakralne i liturgiczne zgromadzenie Izraela ('éd $\bar{a}(h)$ ). Polecenie jest skierowane do Mojżesza, który występuje tu nie tylko jako najwyższy kapłan, ale także w funkcji proroka. Zgodnie jednak ze stylem $\mathrm{P}$ wynikającym z założenia bezpośredniej komunikacji Jahwe z Mojżeszem i Aaronem, nie zaś z ludem, używanie trzeciej osoby jest zabiegiem, który ma wiązać osobę Aarona

${ }^{4}$ R. Pindel, Magia czy Ewangelia?, Kraków 2003, s. 45-78.

${ }^{5}$ R. PIndel, Magia, s. 66.

${ }^{6}$ H. TAwIL, 'Azazel, s. 50. Autor generalnie proponuje identyfikację Azazela z kananejskim idolem o imieniu Mot.

${ }^{7}$ H. TAwIL, 'Azazel, s. 51.

${ }^{8}$ Huryci to lud armenoidalny, prawdopodobnie indoeuropejski, przybyły w III tys. p.n.e. do płn. Mezopotamii i płd. Anatolii. Zniknęli po najeździe tzw. Ludów Morza w XII w. p.n.e. - zob. G. Roux, Mezopotamia, tłum. B. Kowalska, J. Kozłowska, Warszawa 1998, s. 202-204.

${ }^{9}$ Zob. szerzej M. Popko, Huryci, Warszawa 1992. 
z jego następcami i całym ludem Izraela (etiologia). Użycie terminu 'éd $\underline{d} \bar{a}(h)$ („zgromadzenie”) wskazuje na kapłańskie aspiracje reprezentowania ludu w jego całości, i to jako sakralnego zgromadzenia liturgicznego.

Kpł 16, 7: „Weźmie dwa kozły (šenê haśśe ‘̂îim) i postawi je wobec Jahwe, przed wejściem do Namiotu Spotkania”.

Oba kozły, dar ludu, zostają ofiarowane Jahwe. Ważne jest to, że Jahwe zostawiony zostaje wybór (w drodze rzucania losów), który kozioł ma zostać Jemu ofiarowany. Prerogatywy wyboru zostają oddane więc Bogu, jako że sam akt rzucania losów w świetle tekstów biblijnych jest pytaniem skierowanym do Boga, a On jest udzielającym odpowiedzi. Informacja o Namiocie Spotkania ('óhel mô 'ẹd) zdaje się być zabiegiem, w myśl którego obrzęd z czasów Drugiej Świątyni lokowany byłby u początków historii Izraela (etiologia). Zapewne zabieg ten miał też wyrazić naturalną grzeszność narodu od początków jego istnienia jako ludu przymierza.

Kpł 16, 8: „I rzuci Aaron nad dwoma kozłami losy (gôrālôt dla Jahwe (lajhwh) i jeden los dla Azazela ${ }^{10}$ (la '̆azż'zēl).

Sakralny akt losowania, aczkolwiek dokonywany przez człowieka, jest formą interwencji Boga. Pamiętać należy, że kozioł wylosowany dla Azazela ma być obciążony grzechami ludu. Jego odesłanie zaś jest substytucyjną formą odpuszczenia grzechów. Odpuszczanie win i grzechów jest natomiast wyłączną prerogatywą samego Boga. W ten sposób akt losowania staje się w rycie Dnia Pojednania według rozumienia autora kapłańskiego bezpośrednim działaniem Boga na rzecz swego ludu. Uderza tutaj paralelizm: jeden kozioł dla Jahwe, drugi la 'ăzà'zèl.

Problemem zasadniczym jest interpretacja hebrajskiego ' $\breve{a} z \bar{a} ' z \bar{e} l$. ' $\bar{O} z$ oznaczałby „kozła”; 'āzal miałby znaczenie: „iść drogą, oddalać się”. W tym kierunku idzie tłumaczenie greckie LXX oddające wyrażenie hebrajskie

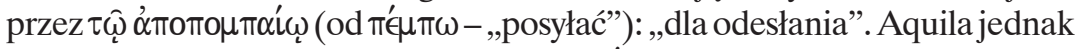
proponuje: $\epsilon \iota \varsigma \kappa \epsilon \kappa \rho \alpha \tau \alpha \iota \omega \mu \epsilon \nu \mathrm{\nu} \nu$ (od $\kappa \rho \alpha \tau \epsilon \epsilon \omega-$, jestem silny, panuję): „ku temu, który jest silny". Wiedzie to ku interpretacji, w myśl której LXX oddałaby dosłownie sens słowa hebrajskiego, Aquila zaś odzwierciedliłby interpretację teologiczną wychodzącą z założenia, że Azazel jest tym, kogo pokonał Jahwe ${ }^{11}$. Czy chodziłoby o jakiegoś przeciwnika Boga, który w świetle literatury apokaliptycznej (żydowskiej, acz pozabiblijnej) został pokonany i zesłany w czeluście, tzn. w miejsce bezludne i bez życia, utożsamiane z pustynią? Wersję tę wspomaga Peszitta, która rozbija termin

${ }^{10} \mathrm{~A}$. Tronina w najnowszym polskim komentarzu do Kpł daje na oznaczenie drugiego kozła tłumaczenie: „wypędzenie”, interpretując termin „azazel” jako złożenie rzeczownika „kozioł” i czasownika „usunąć, oddalić” - A. Tronina, Księga Kaptańska, Częstochowa 2006, s. 236-237.

${ }^{11}$ G. Deiana, Azazel in Lv 16, „Laterantum” 54 (1988) f. 1, s. 18-19. 
hebrajski 'z'zl na $z z^{\prime}$ (,,silny”) i lj', które zmienia na l' („Bóg”). Można zatem przyjąć, że 'ăzā'zēl z TM jest świadomą deformacją literacką, która polega na utworzeniu określenia Azazel. Rozumienie tego terminu jednak nie zmieniło się, o czym świadczy tłumaczenie Peszitta oraz Aquilii ${ }^{12}$.

Kpł 16, 9: „I przyprowadzi Aaron kozła, który był wylosowany dla Jahwe, i uczyni go ( $w^{e}$ ‘áśáh $\left.\hat{u}\right)^{13}$ ofiarą przebłagalną za grzech".

Logiczną konsekwencją jest złożenie ofiary najpierw dla Jahwe. Ma to być akt oczyszczenia, ale brak jest podmiotu owego oczyszczenia. Oczyszczającym jest Jahwe, ale kto zostaje oczyszczony? Czy zatem na pewno chodzi tutaj o akt złożenia ofiary z kozła? Wyrażenie $w^{e}$ ‘āśâhû hațtầt nie musi oznaczać zabicia kozła, ale przygotowanie go do złożenia z niego ofiary, przedstawienie go Jahwe. Co składa się na takie przygotowanie? Niepodobna odpowiedzieć jasno na to pytanie, ale może chodzić o stosowne modlitwy czy gesty. Gdyby bowiem był to akt zabicia kozła wziętego od ludu dla Jahwe, co oznaczałby tekst w. 15: „Potem zabije kozła jako ofiarę przebłagalną za lud”? Trudność stanowi w. 10, który mówi o żywym koźle dla Azazela, co sugerowałoby akt zabicia kozła poprzedniego dla Jahwe. Targum daje tutaj bardzo wieloznaczny termin $w^{e} j a$ ' $\underline{b}^{e} \underline{d} \hat{\imath}$ îh $h$. Jego podstawową ideą jest funkcja służebności podmiotu. Tak więc idąc za Targumem, przetłumaczyć można: „I przyprowadzi Aaron kozła, który był wylosowany dla Jahwe, i który «posłuży» do ofiary przebłagalnej za grzech". Zatem - z uwagi na w. 15 - analogicznie jak w przypadku kozła przeznaczonego do odesłania, przygotowanego przez włożenie rąk symbolizujące złożenie grzechów, chodzi tutaj także o przygotowanie i przedstawienie kozła dla Jahwe do złożenia go w ofierze.

Kpł 16, 10: „A kozła, który został wylosowany dla Azazela, postawi żywego (jo ‘̆mad-haj) wobec Jahwe, aby przebłagać nad nim (lekappēr 'ālâw), żeby odesłać go dla Azazela (la'ăzā'zēl) na pustynię (hammiḍbárā $(h)$ ).

Drugim żywym kozłem także przedstawionym Jahwe jest kozioł przeznaczony do odesłania na pustynię. Nie ma on jednak charakteru ofiary. Nad nim

${ }^{12} \mathrm{~W}$ środowisku helleńskim, zwłaszcza w Syrii Seleucydów, istniała analogia do Azazela („Moc Boża”) - bożek wojny i przewodnik karawan pustynnych Azizo („Moc”); utożsamiano go z gwiazdą poranną, słoneczną, o imieniu Venera, skąd przeszło owo znaczenie do świata greckiego pod imieniem Phosphoros i rzymskiego pod nazwą Lucyfera (od „lux”) - por. HiERONIM (PL 23, 42); w ten sposób Azazel z Henet i Azizo utożsamiane są z gwiazdami; Herodot wzmiankuje boginię Uranię (arab. Alilat - por. hebr. Lilit), utożsamianą z fenicką boginią Asztarte (Isztar), dla Greków to Afrodyta, a dla Rzymian Venus; także u Nabatejczyków znana była bogini al-Uzza (Moc), mająca swój kult i własnych kapłanów; widoczny jest tutaj zjednej strony proces deifikacji gwiazd, z drugiej zaś ich demonizację; w oczywisty sposób stają się one przeciwnikami Boga przymierza, zwłaszcza że w epoce hellenistycznej kulty te były żywe (por. 2 Mch 6,7) - zob. G. DEIANA, Azazel, s. 28-33; starożytne dokumenty greckie zawierają wzmianki o oczyszczająco-przebłagalnym rycie zwanym phármakos, z użyciem człowieka w roli kozła zrzucanego do morza lub kamieniowanego.

${ }^{13}$ BT i inne polskie tłumaczenia podają: ,i złoży go”, co sugeruje akt ofiarniczego zabicia kozła. 
ma zostać dokonany akt przebłagania, który żadną miarą nie zawiera cech ofiary analogicznej do ofiary z kozła dla Jahwe. Kozioł dla Jahwe zostanie zabity, ten zaś odesłany. Sądzić można, że zwrot la 'ăzā'zēl, uwzględniając już wcześniejsze wyjaśnienia co do złożoności tego zwrotu, nie musi być tłumaczony: „dla Azazela”. Hebrajskie apokopowane $l$ ma bardzo szerokie znaczenie i może tutaj oznaczać kierunek ${ }^{14}$. Ponieważ hammid bắrā $(h)$ ma w sobie $h$ locativum, aby nie dawać podwójnego $h$ locativum, użyto $l$. Targum aramejski zawiera tutaj zwrot leceza'zél l'ma $\underline{d} \underline{b}{ }^{e} r \bar{a}$ ', a ponieważ język aramejski nie posiada $h$ locativum, podwójny lamed ma znaczenie kierunkowe. Syryjskie $l$ (lamed) ma analogiczne znaczenie ${ }^{15}$. „Azazel” byłby tutaj równoważnikiem „pustyni”. Można zatem w. 10 przetłumaczyć następująco: „A kozła, który został wylosowany dla Azazela (kozioł + odesłanie), postawi żywego wobec Jahwe, aby przebłagać nad nim, żeby odesłać go na pustynię". Problemem będzie głębsze znaczenie terminu „Azazel”, czym zajmiemy się później.

Inną możliwość stanowi interpretacja $l$ jako lamed wprowadzający do genetivu. Tłumaczenie brzmiałoby wówczas: „A kozła, który został wylosowany (jako kozioł) Azazela, postawi żywego wobec Jahwe, aby przebłagać nad nim, żeby odesłać go na pustynię". Azazel byłby tutaj synonimem zła składanego na kozła, od którego chce uwolnić się Izrael. Zauważyć trzeba bowiem, że nie jest on składany w ofierze, jako akt przebłagalny za grzechy, jak to ma miejsce w przypadku kozła ofiarowanego dla Jahwe.

Co znaczy sam akt odesłania żywego zwierzęcia ${ }^{16}$ ? Odpowiadają na to kolejne wersety.

Kpł 16, 11: „Potem Aaron przyprowadzi cielca na ofiarę przebłagalną za siebie i przebłaga ( $w^{e} k \underline{k i p p e r}$ ) za siebie i za swój dom, i zabije ( $w^{e} \check{s} \bar{a} h a t$ ) cielca na ofiarę przebłagalną za siebie".

Kiedy oba kozły uprzednio wylosowane zostały już przedstawione Jahwe i gotowe są do właściwych dla siebie aktów, konieczne staje się oczyszczenie głównego ofiarnika Aarona. Ponieważ cały tekst Kpł 16 ma charakter etiologiczny, zrozumiałe jest, że chodzi tutaj o każdorazowego arcykapłana uprawnionego do przewodniczenia temu szczególnemu obrzędowi. Aby można było w imieniu ludu i za lud złożyć ofiarę przebłagalną, kapłan winien być absolutnie tożsamy z ludem. Tożsamość tę ujawnia zarówno uznanie własnej grzeszności, jak też wynikająca z niej powinność oczyszczenia. Akt przebła-

${ }^{14}$ P. P. JoüOn, Grammaire de l'hébreu biblique, Rome 1923, s. 405-406.

${ }^{15}$ L. Palacios, Grammatica syriaca, Vicenza 1954, s. 161.

${ }^{16}$ W ST mamy jeszcze dwa przypadki puszczenia żywej ofiary: Kpł 14,7 nakazuje wypuścić żywego ptaka, unurzanego w krwi drugiego ptaka, zabitego jako ofiara dziękczynna za oczyszczenie trędowatego i Kpł 14,53 ma analogiczny nakaz po oczyszczeniu domu z plagi (trudne do interpretacji pojęcie hannágga 'w 14, 40. 48). 
gania kapłana za siebie rozpoczyna zabicie cielca. Kolejne wersety 12, 13 i 14 kontynuują ryt przebłagania kapłańskiego. Drugim elementem rytu jest okadzenie przebłagalni (kappốret ). Trzecim zaś elementem rytu kapłańskiej ofiary przebłagania za siebie jest siedmiokrotne pokropienie nad ('al-p $\left.p^{e} n \hat{e}\right)$ przebłagalnią w kierunku wschodnim krwią zabitego uprzednio cielca.

Kpł 16, 15: „I zabije kozła jako ofiarę przebłagalną za lud, i wniesie krew jego poza zasłonę, i uczyni z krwią jego tak samo, jak uczynił z krwią cielca. Pokropi nią nad przebłagalnią i przed przebłagalnią”.

Następuje właściwy obrzęd przebłagania za lud ( $\left.l \bar{a}^{‘} \bar{a} m\right)$. Właśnie teraz, po przebłaganiu za arcykapłana zostaje zabity najważniejszy przedmiot ofiarniczy - kozioł (śa $\bar{a} \hat{\imath} r)$. Zapewne jest to ten sam kozioł, o którym w. 9 mówił jako o przygotowywanym do ofiary. Analogicznie jak w przebłaganiu za arcykapłana, następuje pokropienie krwią kozła nad przebłagalnią.

Kpł 16, 16: „I przebłaga nad Miejscem Świętym za nieczystości (mițtum'ôt $\underline{\text { t }}$ synów Izraela i za ich przekroczenia (ûmippiš'êhem) według wszystkich ich grzechów. To samo uczyni z Namiotem Spotkania, który znajduje się u nich - w środku ich nieczystości”.

Największą nieczystością (tum'a $(h))$ Izraela było zawsze bałwochwalstwo. W. 16 - jak sądzić można - pojęciem „nieczystości” obejmuje jednak wszelki rodzaj wykroczeń, zarówno w odniesieniu do Prawa czystości (Kpł 11-16), jak i do Prawa Świętości (Kpł 17-26) ${ }^{17}$. Obejmuje więc normy odnoszące się do pokarmów, kontaktów z nieczystymi stworzeniami (zwierzęta, trędowaci, osoby z pewnymi chorobami skóry, kobiety po urodzeniu dziecka, w czasie menstruacji), stosunki seksualne w czasie okresu nieczystości kobiety, cudzołóstwo. Odnosi się więc do rzeczy i do ludzi. W tekstach prorockich, zwłaszcza po deportacji babilońskiej, nieczystość jawi się w kategoriach moralnych najczęściej jako metaforyczne wyrażenie nierządu i cudzołóstwa. Grzechy owe poprzez kult sprawowany przez nieczystych kapłanów, lewitów i ofiarników przenosiły nieczystość na świątynię z jej ołtarzem, stąd oczyszczenie ołtarza. Nieczystość zawsze czyniła człowieka niezdolnym do kontaktu z Bogiem, gdyż powoduje nierównowagę moralną, społeczną i religijną. Wszystkie te nieczystości w jakiś sposób rozumiano jako aktualizację demonicznych sił, które stawały się przeciwnikami Boga. Domagały się zatem jakiejś formy oczyszczenia poprzez obrzęd przebłagania. Także teoforyczny znak obecności Boga (Arka Przymierza z przebłagalnią, bądź samo Święte Świętych w Drugiej Świątyni ${ }^{18}$ ) musiał być oczyszczany.

${ }^{17}$ Kodeks świętości Kpł 17-26 jest wcześniejszego pochodzenia i został zapewne wykorzystany przez kapłanów do stworzenia Prawa czystości (Kpł 11-16).

${ }^{18} \mathrm{O}$ nieobecności Arki w Drugiej Świątyni zob. J. Flawıusz, Wojna żydowska 5, 5, i TACYT, Historia V. 9; A. Mozgol, Arka Przymierza, [w:] Życie religijne w Biblii, red. G. Witaszek, 
Przeciwieństwem nieczystości jest czystość. W tekstach ugaryckich idea czystości związana była z ideą światła i pełni (țhr). Oznaczała dobrą jakość, wewnętrzną doskonałość. Nieczysty nie należy do Boga, który jest Światłością i Pełnią, więc nie może stawać w Jego obecności. Stąd nieomal obsesyjna pogoń Izraela, zwłaszcza w końcowej fazie okresu Drugiej Świątyni, za czystością, która odzwierciedla pozytywną chęć kształtowania Izraela jako narodu świętego, poświęconego Bogu. Przekroczenie ( $\left.p \check{s}^{\circ}\right)$ zawiera w sobie zasadnicze naruszenie relacji między partnerami w postaci niewierności bądź buntu, sprzeniewierzenia bądź otwartego wystąpienia przeciw (por. Ez 2, 3). Wydaje się, że termin ten pozostaje w kontekście Prawa Świętości. Z pewnością ta oryginalnie izraelska myśl wiąże kwestię czystości ludu z przymierzem. Celem wszystkich składanych ofiar miało być odtąd przebłaganie, usunięcie skutków grzechu, aby wrócić do ideału przymierza. Położono więc nacisk na ofiary, które mają charakter przebłagalny. Gest pokropienia przebłagalni krwią ma w ścisłym sensie oznaczać usunięcie grzechów Izraela. Jakie zatem znaczenie miałby gest złożenia grzechów na kozła dla Azazela i odesłanie go?

Kpł 16, 17: „[...] Tak przebłaga za siebie samego, za swój dom i za całe zgromadzenie Izraela".

Wydaje się, że to stwierdzenie zamyka ryt przebłagania. Mowa jest bowiem o zasadniczych elementach rytu: przebłaganiu arcykapłana za siebie oraz przebłaganiu za całego Izraela. Za chwilę nastąpi ryt oczyszczenia ołtarza $(16,18-19)$, a następnie ryt z kozłem wylosowanym do wysłania na pustynię $(16,20-28)$.

Kpł 16, 20: „[...] każe przyprowadzić żywego kozła (haśśā ‘îr hehāj)”.

Po zakończeniu rytu przebłagania za lud oraz rytu przebłagania i oczyszczenia ołtarza, kapłan przewodniczy rytowi związanemu z drugim, żywym kozłem w wyniku losowania $(16,8)$ przeznaczonym do odesłania. Kozioł ten uprzednio został przedstawiony Jahwe $(16,9)$ i przygotowany (we'áśáhhû) do obrzędu.

Kpł 16, 21: „Aaron położy obie ręce na głowę żywego kozła, wyzna ( $\left.w^{e} h i \underline{t} w a d d \bar{a}(h)\right)$ nad nim wszystkie winy (kol-'ăwōnōt) Izraelitów, wszystkie ich przekroczenia (kol-piš‘ êhem) odnoszące się do wszelkich ich grzechów (kol-hațốtām), włoży je na głowę kozła i każe człowiekowi do tego przeznaczonemu wypędzić go na pustynię".

Tekst zawiera potrójne określenie brzemienia składanego na kozła: winy ('āwôn); przekroczenia, wykroczenia (péša ); grzechy (hațtā't $)$. 'Āwôn oznacza czyn niegodziwy, niesprawiedliwy, moralnie oceniany jako zło, które zrywa więź z Bogiem. Należy do nich oszustwo wobec Boga, słowny

Lublin 1999, s. 51. 
fałsz, czyli kłamstwo oraz niegodziwość w postaci idolatrii. Czyny owe powodują skalanie osoby, a więc zaciągnięcie i trwałość - aż do jej usunięcia - winy. Péša 'w Biblii występuje na oznaczenie buntu i rewolty, która jeśli jest skierowana przeciw Bogu, staje się przekroczeniem, a tym samym grzechem. Wykroczenie co prawda może być skierowane przeciw ludziom, ale jeśli narusza normy stanowione przez Boga, przybiera postać grzechu. Termin hatțā't jest chyba najczęściej stosowany przez teksty natchnione ST jako określenie zła. Termin ten odzwierciedla całą refleksję Izraela nad tym, co dziś nazywamy grzechem. Odpowiedni czasownik w qal oznacza akt grzeszny jako taki, tzn. akt, który narusza prawo bądź umowę i czyni oczywistym konieczność kary. Powszechność tego grzechu jest tak duża, że obejmuje nawet obcych, czego przykładem jest wyznanie faraona z Wj 9, 27: „Zgrzeszyłem (hat thầ't̂́l)”. Jakkolwiek bezpośrednim przedmiotem zła jest człowiek, to jednak ten rodzaj zła sprawia, że skutki grzechu odnoszą się do Jahwe. Stąd właśnie wywiedziono ideę oczyszczenia (w osnowie piel) i skonkretyzowano w odniesieniu do samooczyszczenia jednostki (osnowa hitpael). Oczyszczenie zatem w oparciu o $h t$ ’ nabiera znaczenia odpuszczenia grzechów. Wydaje się więc, że symboliczne złożenie wszelkich grzechów i win na kozła i wygnanie go na pustynię obejmować miało wszelki grzech i każdą winę jednostki i całego Izraela. Czy zatem nie należy powiedzieć, że kozioł zabity dla Jahwe był ofiarą przebłagalną usuwającą grzech, działaniem samego Boga? Kozioł przeznaczony do odesłania byłby więc ofiarą oczyszczającą, czyli formą odrzucenia grzechu, aktem woli każdego Izraelity włączającego się w gest nałożenia rąk przez arcykapłana. Dlaczego jednak nie wystarczyło powiedzenie o odesłaniu go na pustynię? Dlaczego owo tajemnicze dopowiedzenie: kozioł la ‘ăzā'zél?

Kpł 16, 22: „W ten sposób kozioł zabierze z sobą wszystkie ich winy do ziemi bezludnej ('el-'éres gezeerāa $(h)$ ). Ów człowiek wypędzi kozła na pustynię (bammid $b \bar{a} r)$ ".

Tekst utożsamia dwa określenia: ziemia bezpłodna ('éreș geēerā $(h)$ ) i pustynia (mid $\underline{d} \bar{a} r$ ). Rdzeń gzr jest wieloznaczny, ale główną ideą jest rozdzielenie. W języku aramejskim dochodzi tutaj idea rozstrzygania, rozsądzania. Zatem o miejscu, na które odsyłany zostaje kozioł, można mówić w kategoriach inności w stosunku do miejsca przebywania ludzi. Tę inność stanowi odludność miejsca, w którym człowiek sam nie byłby w stanie przeżyć. Wysłanie kozła w takie miejsce wskazuje na rozdzielność, na odrzucenie przez Izrael tego, co nie powinno i nie może żyć wespół z ludźmi. Wskazanie na pustynię jako takie miejsce jest zabiegiem kończącym pojęciowe procedowanie: od „Azazela” przez „ziemię bezpłodną” do „pustyni”. Należy też zwrócić uwagę, że nie powtarza się 
tutaj $l+$ Azazel, co świadczyć może o małej jego istotności albo wprost o zawarciu określenia „do - dla Azazela” w określeniu „ziemia bezpłodna” i wreszcie „pustynia” jako efekt końcowy. Przybiera to postać następującą: Azazel $=$ ziemia bezpłodna $=$ pustynia. Wysłanie na pustynię oznaczałoby odesłanie „tam, gdzie panują siły zła”. Takie rozumienie spotykamy także w interpretacji nowotestamentowej: „Gdy duch nieczysty opuści człowieka,

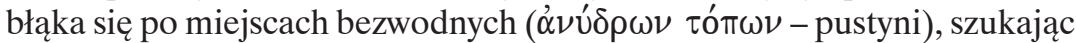
spoczynku, ale nie znajduje" (Mt 12, 43). Opiera się ono na przekonaniu, że chorobę powoduje działanie złego ducha. Tak jest w przypadku Saula: „Odezwali się do Saula jego słudzy: «Oto dręczy cię duch zły, zesłany przez Boga" (1 Sm 16, 15; 19, 9). W helleńskim środowisku księgi Tobiasza wyrażone jest przekonanie, że zły duch (demon) winny jest ludzkich chorób, szczególnie opętania $(6,8)$, a uwalnia od niego ryt magiczny. Także w przekazie ewangelicznym widać wyraźny związek dziwnego w ludzkich oczach postępowania z działaniem złego ducha. Jan Chrzciciel oskarżany jest o takowe opętanie (Mt 11, 18; Łk 7, 33). Świadkowie działalności Jezusa przekazują przekonanie o tym, że Jezus leczy choroby, uwalniając od złego ducha (Mt 17, 18; Mk 7, 29-30; Łk 4, 35).

Henet 10, 4 nakazuje odesłanie Azazela na pustynię, „która jest w Dudael”. Targum Pseudo-Jonatana przekłada Kpł 16, 21-22, idąc właśnie za tradycją henochiczną. Co oznacza termin „Dudael”? Identyfikuje się ten termin z Bet Hadudo (Hudedun), miejscem na południowy-wschód od Jerozolimy, na skraju pustynnego urwiska pustyni Judzkiej ${ }^{19}$. Być może dlatego tradycja rabiniczna nakazuje zrzucić kozła z tego urwistego klifu, zamiast go tylko wypędzić na pustynię, jak to jest w Kpł 16, choć bardziej pragmatyczne zdaje się być uzasadnienie, żeby nie wrócił do ludzi.

Pustynia w realiach człowieka Wschodu jest miejscem, w którym jednostka jest z założenia skazana na niepowodzenie. Stąd pustynia była miejscem karnego odesłania ze społeczności. Tam miało zginąć to, co było nieprawością. Ale jest to rozumienie już z późnego okresu, kiedy Izrael stał się ludem osiadłym i pustynia poczęła jawić mu się w kategoriach negatywnych. U początku swych dziejów pustynia była miejscem wypasu zwierząt. Zapewne więc nie rozumiano jej pierwotnie jako bezkresnych i nieprzyjaznych przestrzeni, ponieważ pierwotny Izrael był ludem seminomadycznym. Pustynia nabrała znaczenia grozy i miejsca kary znacznie później i takie właśnie jej rozumienie widać w Kpł 16. Kozioł tam wysłany miał na pierwszym miejscu wskazać na decyzję separacji zła od dobra. To zaś niewątpliwie przywołuje ideę przymierza.

${ }^{19}$ M. Yoma 6, 8. 
Wielokrotnie w ciagu swej historii Izrael odnawiał przymierze z Bogiem. Najbardziej fundamentalny akt odnowienia przymierza stanowiła decyzja oddzielenia i odrzucenia tego, co przymierzu z Jahwe się sprzeciwiało. Deuteronomista, konkludując ideę przymierza, powiada: „kładę dziś przed wami błogosławieństwo i przekleństwo" (Pwt 11, 26). Podobnie w Pwt 30, 15: „Kładę dziś przed tobą życie i szczęście, śmierć i nieszczęście”. Najmocniej podkreślone zostaje to w Pwt 30, 19: „Biorę dziś przeciwko wam na świadków niebo i ziemię, kładąc przed wami życie i śmierć, błogosławieństwo i przekleństwo. Wybierajcie więc życie, abyście żyli wy i wasze potomstwo”. Teologia prorocka wyraża to następująco: „Do tego narodu zaś powiedz: To mówi Jahwe: Oto stawiam przed wami drogę życia i drogę śmierci” (Jr 21, 8). Myśl ta znalazła się w biblijnym mesjanizmie: „Śmietanę i miód spożywać będzie, aż się nauczy odrzucać zło, a wybierać dobro" (Iz 7, 15).

Kraków

SYLWESTER JEDRZEJEWSKI SDB

\section{Summary}

\section{Goat for Azazel}

The rite included in Leviticus 16 belongs to penitential rites of purification. It may be a reminiscence of antic religious medical-magic rites, practiced in multiple regions of ancient world. The rites contained the idea of substitution, "magic elimination." Sending the goat represents rejection of anything that should not and can not exist among the people of Israel. The desert as an "infertile" place, the theological idea of separating the good from the evil as well as the ancient idea of substitution point at the theology of penance expressed in the rite of separation. The text of Leviticus 16 applies the term sa ir for the goat. The same term is also applied in priestly text to describe demons relating to the misshapen form of Israel religion. There is an undoubted connection with the idea of Convenant that constitutes the basic background and point of reference for the rite of Leviticus 16 . 